\title{
PENGARUH KUALITAS PELAYANAN TERHADAP LOYALITAS KONSUMEN DENGAN KEPUASAN KONSUMEN SEBAGAI VARIABEL PEMODERASI (STUDI KASUS PADA KONSUMEN GOJEK DI KOTA BANJARMASIN)
}

\author{
Boy Sapto Suryo Subiantoro \\ ASMI Citra Nusantara di Banjarmasin \\ Jl. Soetoyo S. No. 197 Banjarmasin \\ E-mail: boy_sapto60@yahoo.co.id
}

\begin{abstract}
The presence of transportation services in the network is currently a separate phenomenon in the community. Where many services are provided in order to facilitate consumers both in terms of transportation and other services. And to find out the relationship between service quality and consumer loyalty, both directly and through customer satisfaction variables in consumers of transportation companies in the network, namely Gojek in Banjarmasin, the research was conducted using data collection media, namely questionnaires. Testing data using multiple linear regression analysis, as well as through the test results of the multak difference. Based on multiple linear regression testing conducted, it is known that both together and partially service quality variables and customer satisfaction can affect customer loyalty with a significant value obtained below the level of significant 5\%. While testing the relationship of service quality to customer loyalty through customer satisfaction by performing the absolute difference test results in a significant value of 0.157 or more than the level of significant 0.05 so that the results are declared no influence.
\end{abstract}

Keywords: Quality of Service, Consumer Satisfactions, Consumer Loyalty, Online Transportation Service

\begin{abstract}
Abstrak
Kehadiran jasa transportasi dalam jaringan saat ini menjadi fenomena tersendiri di lingkungan masyarakat. Dimana banyak pelayanan yang diberikan dalam rangka memudahkan konsumennya baik dari sisi transportasi maupun pelayanan lainnya. Dan untuk mengetahui hubungan kualitas pelayanan terhadap loyalitas konsumen, baik secara langsung maupun melalui variabel kepuasan konsumen pada konsumen perusahaan transportasi dalam jaringan, yaitu Gojek di Kota Banjarmasin, maka penelitian ini dilakukan dengan menggunakan media pengumpulan data yaitu kuesioner. Pengujian data menggunakan analisis regresi linear berganda, serta melalui uji hasil selisih multak . Berdasarkan pengujian regresi linear berganda yang dilakukan, diketahui bahwa baik secara bersama-sama maupun secara partial variabel kualitas layanan dan kepuasan konsumen dapat mempengaruhi loyalitas konsumen dengan nilai signifikan yang dipeoleh di bawah level of significant 5\%. Sedangkan pengujian hubungan kualitas layanan terhadap loyalitas konsumen melalui kepuasan konsumen dengan melakukan hasil uji selisih mutlak menghasilkan nilai signifikan 0,157 atau lebih dari level of significant 0.05 sehingga hasilnya dinyatakan tidak tidak ada pengaruh.
\end{abstract}

Kata kunci : Kualitas Layanan, Kepuasan konsumen, Loyalitas Konsumen, Jasa Transportasi Dalam Jaringan 


\section{PENDAHULUAN}

Di era bisnis yang saat ini semakin berkembang, semua pelaku bisnis senantiasa dituntut untuk peka akan kondisi social dan ekonomi yang berkembang di masyarakat. Terutama pada masa industri 4.0 yang saat ini sedang berlangsung. Saat ini konsumen benar-benar menuntut semua kegiatannya dapat dilaksanakan secara cepat dan efisien dalam bidang apapun, termasuk dalam kegiatan pemenuhan kebutuhan sehari-hari. Sehingga bisnis penyedia jasa khusus dalam rangka kegiatan tersebut yang didukung oleh kemajuan teknologi dan komunikasi menjadi salah satu bisnis yang menjanjikan.

Lovelock (2005:5) mengutarakan bahwa jasa merupakan suatu tindakan atau adanya kinerja yang ditawarkan suatu pihak kepada pihak lainnya. Secara proses kegiatan ini berkaitan dengan produk fisik, namun kinerjanya pada dasarnya tidak nyata serta biasanya tidak menghasilkan kepemilikan atas faktor-faktor produksi. Stanton (1986:529) menyatakan jika jasa secara terpisah, tidak berwujud dan ditawarkan untuk mememnuhi kebutuhan dimana jasa dapat dihasilkan dengan menggunakan benda-benda berwujud atau tidak.

Gojek sebagai salah satu perusahaan teknologi asal Indonesia dalam rangka melayani 17 jasa online yaitu jasa ojek online, jasa pesan antar, taksi online, layanan pemesanan makanan, jasa pesan tiket, layanan kecantikan, layanan kebersihan rumah, layanan pijat, layanan montir, layanan isi pulsa, layanan berbagai pembayaran, layanan pembelian obat, layanan transportasi barang, layanan pengantaran barang ukuran besar, layanan belanja barang, layanan pembayaran digital, layanan penawaran diskon, layanan transportasi dengan mobil. Perusahaan ini muncul di Indonesia sejak 2010 namun baru 2017 hadir di kota Banjarmasin. Banyaknya fitur layanan jasa yang ditawarkan memberikan ruang bagi konsumen mengenai layanan apa yang diinginkan konsumen sesuai dengan kebutuhannya secara mudah.

Pada dasarnya perusahaan memiliki kewajiban dalam memenuhi target laba setiap tahun, laba tentunya didapat dari pendapatan yang berasal dari penjualan. Penjualan akan stabil jika konsumen puas akan barang atau jasa yang kita tawarkan. Kotler (2007:61) menyatakan bahwa kepuasan merupakan adanya perasaan senang atau kecewa pada seseorang seseorang yang muncul setelah adanya kegiatan untuk membandingkan kinerja (hasil) dari produk yang dipikirkan terhadap kinerja (hasil) dari produk yang diharapkan.

Saat hubungan kepuasan pelanggan pada kualitas pelayanan yang semakin tinggi, maka dapat menimbulkan keuntungan bagi usaha itu sendiri. Salah satu faktor yang menentukan kepuasan pelanggan adalah persepsi pelanggan mengenai kualitas jasa yang berfokus pada lima dimensi kualitas pelayanan, yaitu: bukti fisik (tangible), keandalan (reliability), daya tanggap (responsiveness), jaminan (assurance), dan empati (empathy).

Faktor penting lain bagi keberhasilan suatu usaha dalam menghadapi persaingan yang kompetitif adalah adanya loyalitas pelanggan. Terciptanya loyalitas pelanggan akan memungkinkan perusahaan mengembangkan hubungan jangka panjang dengan konsumen. Loyalitas konsumen adalah hubungan emosional konsumen dengan perusahaan yang didasarkan atas kecintaan konsumen atas produk dan jasa yang ditawarkan dan dibuktikan dengan keinginan melakukan pembelian ulang (Barnes, 2003: 38).

Penelitian kualitas pelayanan terhadap loyalitas pelanggan yang melibatkan variable 
kepuasan konsumen sebagai variabel pemoderasi memiliki beberapa perbedaan hasil penelitian. Fatona (2010) menyatakan kualitas layanan jasa terhadap kepuasan konsumen memiliki hubungan positif dan signifikan, namun jika kualitas layanan jasa dimoderasi dengan kepuasan nasabah kredit BPR-BKK Karangmalang Kabupaten Sragen tidak memiliki pengaruh terhadap kepuasan konsumen. Askari (2014, 1-10) meneliti Pengaruh Kualitas Pelayanan Terhadap Loyalitas Pelanggan Dengan Kepuasan Pelanggan sebagai Variabel Moderating (Bagian Service PT. Nasmoco Gombel Semarang) menemukan hubungan yang signifikan dan positif. Demikian pula penelitian Kumalaningrum, dkk (2016) dengan variabel yang sama dengan studi pada konsumen CS kopi Tubruk Surakarta menemukan hubungan yang positif dan signifikan.

Penelitian ini bertujuan untuk mengetahui apakah variabel kualitas pelayanan dan variable kepuasan mampu mempengaruhi loyalitas pelanggan secara parsial. Serta ingin mengetahui apakah variabel kualitas pelayanan yang dimoderasi oleh variabel kepuasan pelanggan dapat mempengaruhi variabel loyalitas konsumen.

\section{TINJAUAN PUSTAKA}

\section{Kualitas Layanan}

Kualitas pelayanan berpusat pada upaya pemenuhan kebutuhan dan keinganan serta ketepatan penyampaiannya untuk mengimbangi harapan pelanggan. Dan Wyckof dalam Tjiptono (2006:260) menyatakan kualitas jasa adalah tingkat keunggulan yang diharapkan dan pengendalian atas tingkat keunggulan tersebut untuk memenuhi keinginan pelanggan.

Kualitas pelayanan adalah keseluruhan ciri-ciri dan karakteristik-karakteristik dari suatu produk atau jasa dalam hal kemampuannya untuk memenuhi kebutuhankebutuhan yang telah ditentukan atau bersifat laten (Lupioyadi, 2001; 144). Jika pelayanan yang diterima atau dirasakan pelanggan sesuai dengan ekspektasi (apa yang diharapkan) maka kualitas dapat dipersepsikan dengan baik dan memuaskan pelanggan. Sebaliknya jika ekspektasi pelanggan lebih rendah dari apa yang dirasakan secara nyata, maka kualitas dapat dipersepsikan secara buruk atau tidak memuaskan.

Kualitas pelayanan sangat bergantung pada tiga hal, yaitu sistem, teknologi dan manusia. Perusahaan yang bergerak di bidang jasa sangat bergantung pada kualitas jasa yang diberikan. Kotler (2002), ada lima dimensi kualitas pelayanan penjualan yang dapat meningkatkan kepuasan konsumen, sebagai berikut :

1. Keandalan (Reliability) yaitu Kemampuan untuk melaksanakan pelayanan pada konsumen yang dijanjikan secara terpercaya dan akurat.

2. Daya Tanggap (Responsiveness) yaitu Kemampuan untuk membantu, melayani dan memberikan pelayanan dengan cepat dari perusahaan kepada konsumen.

3. Kepastian (Confidence) yaitu Pengetahuan dan kesopanan yang dimiliki karyawan perusahaan, serta kemampuan mereka untuk menimbulkan kepercayaan dan keyakinan pada konsumen.

4. Empati (Empathy) yaitu Kesediaan untuk peduli kepada konsumen, dan memberikan perhatian secara pribadi kepada konsumen yang membutuhkan pelayanan.

5. Berwujud (Tangible) yaitu Penampilan fisik yang dimiliki perusahaan, peralatan, petugas, karyawan dan materi komunikasi yang ada pada perusahaan. 


\section{Kepuasan Konsumen}

Kata kepuasan (satisfaction) berasal dari bahasa latin satis artinya cukup baik, memadai dan facio artinya melakukan atau membuat. Tjiptono (2006: 147) kepuasan konsumen adalah tingkat perasaan seseorang setelah membandingkan kinerja (hasil) yang ia rasakan dibandingkan dengan harapannya. Keller dan Kotler (2009:138-139) mengatakan bahwa kepuasan (satisfaction) adalah perasaan senang atau kecewa seseorang yang timbul karena membandingkan kinerja yang dipersepsikan produk (atau hasil) terhadap ekspetasi mereka.

Kepuasan pelanggan telah didefinisikan dalam berbagai cara, tetapi secara konseptual hal ini tampaknya telah mencapai penerimaan terluas adalah bahwa kepuasan merupakan penilaian pasca-pilihan evaluatif transaksi tertentu (Bastos dan Gallego, 2008:5). Wilkie (1994,27) menyatakan bahwa kepuasan konsumen atau pelanggan merupakan respon emosional terhadap evaluasi pengalaman mengkonsumsi produk, toko atau jasa. Terdapat lima elemen pada kepuasan konsumen yaitu expectations (harapan), performance (kinerja), comparison (perbandingan), confirmation (harapan yang tercapai) atau disconfirmation (harapan yang tidak tercapai), dan discrepancy (ketidak sesuaian) (Wilkie, 1994; Bulkia, 2018; Wicaksono, 2017). Kesimpulannya, kepuasan merupakan tingkat perasaan konsumen yang diperoleh setelah konsumen melakukan atau menikmatisesuatu dimana alternatif yang dipilih sekurang-kurangnya memberi hasil sama atau melampaui harapan konsumen

Bagi perusahaan memiliki arti tersendiri untuk setiap pelanggannya. Mowen dan Minor (2002:114), memaparkan bahwa kepuasan konsumen dipengaruhi oleh keadilan yang dirasakan, harapan yang dibuat oleh konsumen dan pelaksanaan aktual dari pelayanan. Kepuasan disinyalir dapat membentuk antusiasme pelanggan untuk loyal terhadap perusahaan. Pelanggan memang memiliki pola pikir yang berbedabeda, ada pelanggan yang tidak peduli apakah mereka puas atau tidak atas jasa atau barang yang mereka konsumsi, namun sebagian besar pelanggan yang lain layak untuk dapat perhatian dan pelayanan prima atas jasa atau barang yang mereka konsumsi. Dengan demikian, perusahaan harus memiliki analisa-analisa terkait kepuasan pelanggan dalam rangka menciptakan loyalitas perusahaan.

Menurut Zeithaml dan Bitner (2000:75) definisi kepuasan adalah :Respon atau tanggapan konsumen mengenai pemenuhan kebutuhan. Kepuasan merupakan penilaian mengenai ciri atau keistimewaan produk atau jasa itu sendiri, yang menyediakan tingkat kesenangan konsumen berkaitan dengan pemenuhan kebutuhan konsumsi konsumen.Bila kepuasan pelanggan dilihat dari persepsi dan harapan, maka akan mengacu pada The First Law of Service,

Dimana : Kepuasan sama dengan persepsi dikurangi harapan ( $\mathrm{S}=\mathrm{P}-\mathrm{E}$ )

Keterangan :

$\mathrm{S}=$ Satisfaction atau tingkat kepuasan pelanggan

$\mathrm{P}=$ Perception atau persepsi pelanggan

$\mathrm{E}=$ Expectation atau harapan pelanggan

\section{Loyalitas Pelanggan}

Loyalitas pelanggan menjadi hal yang penting bagi perusahaan dalam mempertahankan kelangsungan hidup usahanya. Pelanggan yang setia adalah pelanggan yang merasa puas atas jasa atau barang yang mereka konsumsi, dan berpeluang memberikan referensi kepada 
orang lain untuk menjadi konsumen baru perusahaan tersebut.

Griffin (2005:49) menyatakan bahwa "Pelanggan harus dianggap sebagai individu dan diperlakukan sedemikian rupa agar tetap loyal dan membantu perusahaan tetap tumbuh dan terus berkembang". Usaha untuk memperoleh pelanggan yang loyal tidak bisa dilakukan perusahaan secara instan ataupun sekaligus, tetapi melalui beberapa proses, mulai dari mencari pelanggan potensial hingga memperoleh partner. Oliver dalam Hurriyati (2008:129) menjelaskan pengertian loyalitas adalah komitmen pelanggan bertahan secara mendalam untuk berlangganan kembali atau melakukan pembelian ulang produk atau jasa terpilih secara konsisten di masa yang akan datang, meskipun pengaruh situasi dan usaha-usaha pemasaran mempunyai potensi untuk menyebabkan perubahan perilaku.

\section{Kerangka Berpikir}

Pengembangan dari kerangka Pikir dalam penelitian ini secara teoritis adalah bahwa loyalitas konsumen dipengaruhi oleh variabel kualitas pelayanan dan variabel kepuasan konsumen. Selanjutnya kepuasan konsumen akan memoderasi pengaruh kualitas pelayanan terhadap kepuasan konsumen.

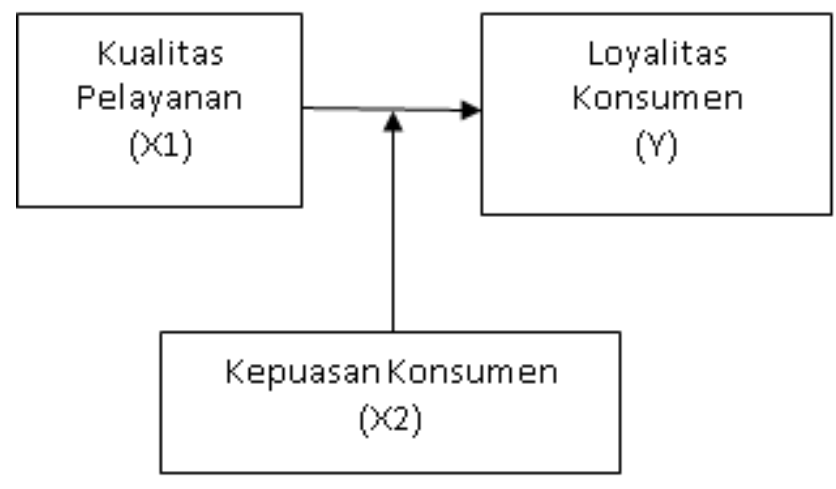

Gambar 1. Model Kerangka Berpikir

\section{Keterangan:}

Variabel Independen $(X 1)=$ Kualitas Pelayanan Variabel Moderasi $(\mathrm{X} 2)=$ Kepuasan Konsumen Variabel Depensen $(\mathrm{Y})$ = Loyalitas Konsumen

\section{Hipotesis}

Dari kerangka pikir yang dipaparkan sebelumnya, maka hipotesis yang dikembangkan penelitian ini antara lain:

$$
\begin{aligned}
\mathrm{H}_{1}= & \text { Kualitas pelayanan berpengaruh } \\
& \text { terhadap loyalitas konsumen } \\
\mathrm{H}_{2}= & \begin{array}{l}
\text { Kepuasan Konsumen berpengaruh } \\
\text { terhadap loyalitas konsumen }
\end{array} \\
\mathrm{H}_{3}= & \begin{array}{l}
\text { Kualitas berpengaruh terhadap } \\
\text { loyalitas konsumen pelayanan melalui } \\
\text { kepuasan konsumen }
\end{array}
\end{aligned}
$$

\section{METODE PENELITIAN}

Jenis, Lokasi dan Waktu Penelitian

Berdasarkan latar belakang dan tujuan penelitian yang ingin dicapai, maka penelitian ini dapat digolongkan sebagai penelitian eksplanatori. Penelitian ini dilakukan di wilayah Kota Banjarmasin periode Maret - Agustus 2019.

Populasi dan Sampel 
Populasi dalam penelitian ini adalah semua warga kota Banjarmasin yang pernah menggunakan jasa Gojek dalam 17 layanan yang terdapat dalam fitur layanan gojek periode pengamatan. Pemilihan sample dilakukan peneliti terhadap populasi dengan metode kebetulan (accidential sampling) ditemui pada pengguna yang diketahu selesai melakukan transaksi di aplikasi gojek sebanyak 98 orang.

\section{Definisi Operasional}

Mengacu pada penelitian sebelumnya, maka definisi operasional ditetapkan sebagai berikut.

Kualitas Pelayanan yaitu suatu aktivitas yang dilakukan agar mendapatkan apresiasi puas dari konsumen atas kegiatan yang sedang berlangsung. Indicator yang dipakai untuk mengukur kepuasan konsumen Zeithaml, Bitner dan Gremler (2009:111), yaitu: reability, responsiveness, assurance, empathy, dan tangible.

Kepuasan konsumen adalah perasaan senang atau kecewa seseorang yang muncul setelah membandingkan antara kinerja (atau hasil) produk yang dipikirkan terhadap kinerja (atau hasil) yang diharapkan Indikatorindikator variabel kepuasan pelanggan dalam penelitian ini mengacu pada teori yang dikemukakan oleh Kotler (2007: 206) meliputi:

a) Puas terhadap kualitas pelayanan.

b) Merekomendasikan produk/jasa kepada orang lain.

c) Memiliki keinginan untuk tidak berpindah ke produk/jasa yang lain.

d) Bangga menggunakan jasa/produk yang digunakan.

e) Puas terhadap hasil akhir produk/jasa yang diterima.
Loyalitas Konsumen

Menurut Loyalitas adalah respon perilaku pembelian yang dapat terungkap secara terus menerus oleh pengambil keputusan dengan memperhatikan satu atau lebih merek alternative dari sejumlah merek sejenis dan merupakan fungsi proses psikologis. Indikatornya diambil dari Deng, Lu, Wei, and Zhang (2010, 289-300) yaitu saying a positif thing, recommended to other, continue purchasing.

\section{Teknik Pengumpulan Data}

Teknik pengumpulan data untuk penelitian ini menggunakan kuesioner yang diberikan kepada 98 responden. Kemudian data tentang tanggapan responden yang diukur dengan skala Likert 5 poin yaitu Sangat Setuju (5), Setuju (4), Netral (3), Tidak Setuju (2). Sangat Tidak Setuju (1).

\section{Pengujian Data}

Untuk menguji kualitas data dilakukan uji validitas dan reliabilitas instrument menggunakan rumus Korelasi Pearson dan Cronbach Alpha. Korelasi pearson yang di isyaraatkan adalah $\geq 0.5$ sedangkan untuk pengujian kesahihan data dengan menggunakan alpha Cronbach $\geq 0.6$.

\section{Teknik Analisis Data}

Proses analisis data dalam penelitian ini dilakukan melalui tiga tahapan yaitu pengujian prasyarat dan pengujian hipotesis. Pengujian prasyarat untuk pengujian regresi dimulai dengan melakukan pengujian asumsi klasik dimana dilakukan pengujian normalitas data, Uji Multikolinieritas, Uji Autokolerasi dan Uji Heterokedastisitas.

Pengujian Hipotesis 1 dan 2 dengan menggunakan uji analisis regresi berganda untuk menguji mengetahui hubungan antara 
pengaruh kualitas pelayanan (X1) terhadap Loyalitas Konsumen (Y) serta Kepuasan Konsumen (X2) terhadap Loyalitas Konsumen (Y). Pengujian terhadap hipotesis ke 3 dimana menguji selisih mutlak dalam menganalisis pengaruh kualitas pelayanan (X1) terhadap loyalitas (Y) konsumen melalui kepuasan konsumen (X2).

\section{HASIL DAN PEMBAHASAN}

\section{Hasil}

Deskripsi Responden

Tabel 1 menyajikan sebaran karakteristik responden berdasarkan jenis kelamin, usia, dan pekerjaan. Dari data tersebut diketahui bahwa berdasarkan jenis kelamin, terdapat 32 orang wanita $(32.7 \%)$ dab 66 orang pria (67.3). Distribusi frekuensi usia menunjukkan bahwa responden yang berusia 17 - 25 tahun sebanyak 34 orang (34.7\%), usia $26-24$ tahun sebanyak 37 orang (37.8\%), dan lebih dari 35 tahun sebanyak 27 orang (27.6\%). Distribusi frekuensi berdasarkan pekerjaan menunjukkan bahwa responden yang berstatus mahasiswa sebanyak 35 orang (35.7\%), swasta 37 orang (37.8\%), PNS/ASN sebanyak 20 orang $(20.4 \%)$ dan yang berprofesi selain yang disebutkan sebanyak 6 orang $(6.1 \%)$.

\section{Uji Validitas dan Reliabilitas}

Uji Validitas memiliki Syarat minimum untuk dianggap suatu butir instrument valid adalah nilai indeks valid adalah nilai indeks validitasnya $\geq 0,3$ (Sugiyono, $2016: 179$ ). Dan uji reliabilitas menggunakan batas nilai korelasi 0,7 maka dikatakan item tersebut memberikan tingkat reliabilitas yang cukup, sebaliknya apabila nilai korelasi dibawah 0,7 maka dikatakan item tersebut kurang reliable (Sugiyono, 2016: 192). Hasil dari uji validitas dan reliabilitas ditunjukkan pada tabel 2. Dari data tersebut diketahui bahwa seluruh item telah memenuhi persyaratan untuk dilakukan pengujian data berikutnya.

\section{Uji Asumsi Klasik}

Uji Normalitas Data bertujuan untuk menguji apakah dalam model regresi ditemukan adanya korelasi antara variabel bebas (Ghozali,2013: 103). Pengujian menggunakan uji kolmogorov smirnov dengan melihat nilai Asymp. Sig. (2-tailed). Apabila terdapat tingkat signifikansinya lebih dari 0,05 maka dapat disimpulkan bahwa $\mathrm{H}_{0}$ diterima, atau bisa dikatakan bahwa data residual berdistribusi normal

Uji Multikolinieritas, dilakukan dengan dilihat nilai tolerance dan variance inflation factor (VIF), Jika terdapat nilai tolerance value > 0,10 atau VIF lebih < 10 maka dapat disimpulkan tidak terjadi multikolinearitas (Santoso. 2002: 206).

Uji Autokolerasi menurut Santoso. (2002: 219) dilakukan melalui uji Durbin-Watson (D-W), dengan tingkat kepercayaan $\alpha=5 \%$. Apabila D-W terletak antara -2 sampai +2 maka tidak ada autokorelasi.

Uji Heterokedastisitas menurut Gujarati (2012: 406) menggunakan uji rankSpearman yaitu dengan cara mengkorelasikan variabel independen terhadap nilai absolut dari residual (error).

\section{Uji Regresi Linear Berganda}

Pengujian pengaruh kualitas pelayanan dan kepuasan konsumen terhadap loyalitas konsumen melalui pengolahan data SPSS versi 24 dirangkum dalam tabel 4 .

Berdasarkan tabel 4, maka persamaan regresi linear berganda pada penelitian ini dapat diketahui sebagai berikut:

$$
Y=1.922+0.289 X 1+0.397 X 2
$$


Persamaan tersebut dapat dijabarkan antara lain:

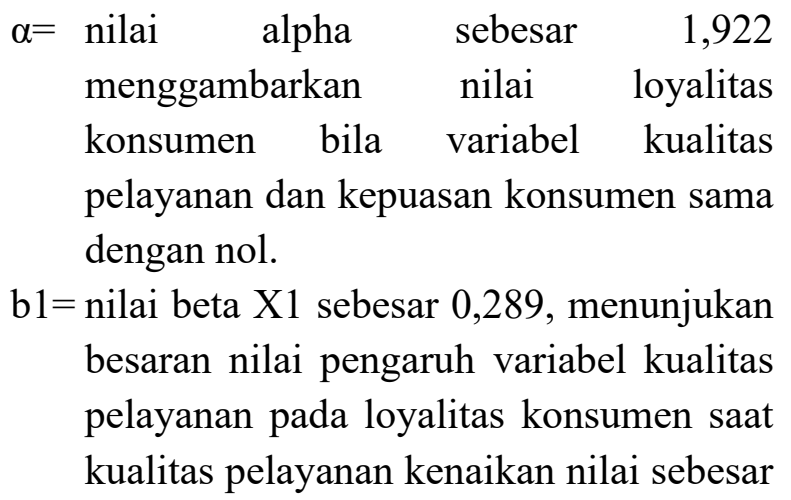

1, dengan asumsi kepuasan konsumen sama dengan tetap atau nol, maka loyalitas konsumen naik menjadi $28,9 \%$. $\mathrm{b} 2=0,397$ atau nilai beta X2 yang menunjukan saat kepuasan konsumen naik sebesar satu, dan kualitas pelayanan sama dengan nol atau tetap, maka terjadi kenaikan nilai loyalitas konsumen sebesar 39,7\%.

Tabel 1. Distribusi Frekuensi Responden

\begin{tabular}{|l|l|c|c|}
\hline Karakteristik & \multicolumn{1}{|c|}{ Keterangan } & Jumlah & \% \\
\hline Jenis Kelamin & Pria & 32 & 32.7 \\
\cline { 2 - 4 } & Wanita & 66 & 67.3 \\
\cline { 2 - 4 } & Total & 98 & 100 \\
\hline \multirow{4}{*}{ Usia } & $17-25$ Tahun & 34 & 34.7 \\
\cline { 2 - 4 } & $26-35$ Tahun & 37 & 37.8 \\
\cline { 2 - 4 } & $>$ 35 Tahun & 27 & 27.6 \\
\cline { 2 - 4 } & Total & 98 & 100 \\
\hline Pekerjaan & Pelajar/Mahasiswa & 35 & 35.7 \\
\cline { 2 - 4 } & Swasta & 37 & 37.8 \\
\cline { 2 - 4 } & PNS/ASN & 20 & 20.4 \\
\cline { 2 - 4 } & Lainnya & 6 & 6.1 \\
\cline { 2 - 4 } & Total & $\mathbf{9 8}$ & $\mathbf{1 0 0}$ \\
\hline
\end{tabular}

Sumber: Data diolah, 2019

Hasil Pengujian Hipotesis

Dari hasil uji t (partial) yang ditunjukkan pada tabel 4 menunjukkan bahwa pengaruh kualitas pelayanan terhadap loyalitas konsumen diketahui nilai signifikannya adalah 0,000 atau berada di bawah level of significant 5\%. Berarti hipotesis pertama (H1) dinyatakan diterima.

Pengujian untuk hipotesis ke dua (H2) yang menguji hubungan partial untuk variabel kepuasan konsumen terhadap loyalitas memperoleh nilai signifikan sebesar 0,003 atau berada di bawah level of significant $5 \%$, yang berarti bahwa hipotesis ke dua juga dapat dinyatakan diterima.
Hasil Uji F (simultan)

Hasil Uji $F$ pada tabel 4 menunjukan angka signifikan sebesar 0,000 yang berada di bawah level of significant sebesar 5\% yang berarti model ini dianggap tepat menggambarkan hubungan kualitas pelayanan, kepuasan konsumen terhadap loyalitas konsumen. Dengan nilai R Square (Koefisiensi determinasi) sebesar 0.414 mengindikasikan pengaruh variabel kualitas pelayanan dan kepuasan konsumen hanya sebesar 41,4\% mempengaruhi loyalitas konsumen. Sedangkan $58,6 \%$ nya dipengaruhi oleh faktor atau variabel yang tidak diteliti dalam penelitian ini 
Tabel 2. Uji Validitas dan Reliabilitas Konstruk

\begin{tabular}{|c|c|c|c|c|}
\hline No & Pertanyaan & Pear-son & $\begin{array}{l}\text { Cronbach } \\
\text { Alpha }\end{array}$ & Ketera-ngan \\
\hline \multicolumn{5}{|c|}{ Kualitas Layanan (X1) } \\
\hline 1 & Pelayanan Jasa GoJek Dapat diandalkan & 0.73 & 0.897 & Valid dan Reliabel \\
\hline 2 & $\begin{array}{l}\text { Daya Tanggap Driver GoJek atas Permintaan } \\
\text { Konsumen Sangat Cepat }\end{array}$ & 0.681 & 0.899 & Valid dan Reliabel \\
\hline 3 & $\begin{array}{l}\text { Kepastian Pelayanan GoJek Dapat Dipertanggung } \\
\text { Jawabkan }\end{array}$ & 0.694 & 0.899 & Valid dan Reliabel \\
\hline 4 & $\begin{array}{l}\text { Driver Gojek dan Pengelolanya Sangat } \\
\text { Memperhatikan Kebutuhan Konsumen }\end{array}$ & 0.577 & 0.905 & Valid dan Reliabel \\
\hline 5 & $\begin{array}{l}\text { Tampilan Aplikasi dan Driver GoJek dapat mudah } \\
\text { dikenali dan berciri khas perusahaan }\end{array}$ & 0.64 & 0.901 & Valid dan Reliabel \\
\hline \multicolumn{5}{|c|}{ Kepuasan Konsumen $(\mathrm{X} 2)$} \\
\hline 1 & Saya Merasa Kualitas Layanan Gojek Berkualitas & 0.67 & 0.9 & Valid dan Reliabel \\
\hline 2 & $\begin{array}{l}\text { Saya Mau Merekomendasikan GoJek sebagai Jasa } \\
\text { Transportasi yang Bagus }\end{array}$ & 0.68 & 0.899 & Valid dan Reliabel \\
\hline 3 & $\begin{array}{l}\text { Saya Nyaman Memakai Jasa Transportasi Online } \\
\text { (GoJek) }\end{array}$ & 0.56 & 0.908 & Valid dan Reliabel \\
\hline 4 & $\begin{array}{l}\text { Saya Bangga Memakai Jasa Transportasi Online } \\
\text { (GoJek) }\end{array}$ & 0.72 & 0.898 & Valid dan Reliabel \\
\hline 5 & $\begin{array}{l}\text { Saya Puas Memakai Jasa Transportasi Online } \\
\text { (GoJek) }\end{array}$ & 0.67 & 0.901 & Valid dan Reliabel \\
\hline \multicolumn{5}{|c|}{ Loyalitas Konsumen $(\mathrm{Y})$} \\
\hline 1 & Saya Merasa Kehadiran Gojek sangat Membantu & 0.77 & 0.895 & Valid dan Reliabel \\
\hline 2 & Saya Merekomendasikan Gojek Ke Orang Lain & 0.83 & 0.891 & Valid dan Reliabel \\
\hline 3 & $\begin{array}{l}\text { Saya Senang Memakai Jasa GoJek secara } \\
\text { berkelanjutan }\end{array}$ & 0.75 & 0.896 & Valid dan Reliabel \\
\hline
\end{tabular}

Sumber: Data diolah, 2019

Tabel 3 : Hasil Uji Asumsi Klasik

\begin{tabular}{|l|l|c|}
\hline \multicolumn{1}{|c|}{ Uji Asumsi Klasik } & \multicolumn{1}{c|}{ Hasil Uji } & Kesimpulan \\
\hline Uji Normalitas & Asymp Sig. $0.200>0.05$ & Residual Normal \\
\hline Uji Multikolinearitas & VIF $1.708<10$ & Tidak Ada Multikolinearitas \\
\hline Uji Autokolerasi & DW 1.362 (antara -2 sd. 2$)$ & Tidak Ada Autokolerasi \\
\hline Uji Heterokedastisitas & (p1 0.00, p2 0.001$)<0.05$ & Tidak Ada Heterokedastisitas \\
\hline
\end{tabular}

Sumber: Hasil Olah Data SPSS, 2019

Tabel 4. Pengujian Hipotesis (Analisis regresi linear berganda)

\begin{tabular}{|l|c|r|r|l|}
\hline \multicolumn{1}{|c|}{ Variabel Independen } & Beta & \multicolumn{1}{c|}{ Sig. } & \multicolumn{1}{c|}{ T-hitung } & \multicolumn{1}{|c|}{ Keterangan } \\
\hline Konstanta (b) & 1,922 & & & \\
\hline Kualitas Pelayanan (X1) & 0.289 & 0.000 & 3.800 & Signifikan \\
\hline Kepuasan Konsumen (X2) & 0.397 & 0.003 & 3.102 & Signifikan \\
\hline Adjust R Square & $0.401 \quad$ F Hitung & 33.511 & \\
R Square & $0.414 \quad$ Sig. & 0.000 & \\
R & 0.643 & N & 98 & \\
\hline
\end{tabular}

Variabel Dependen: Loyalitas Konsumen (Y)

Sumber: Hasil Olah Data SPSS, 2019 


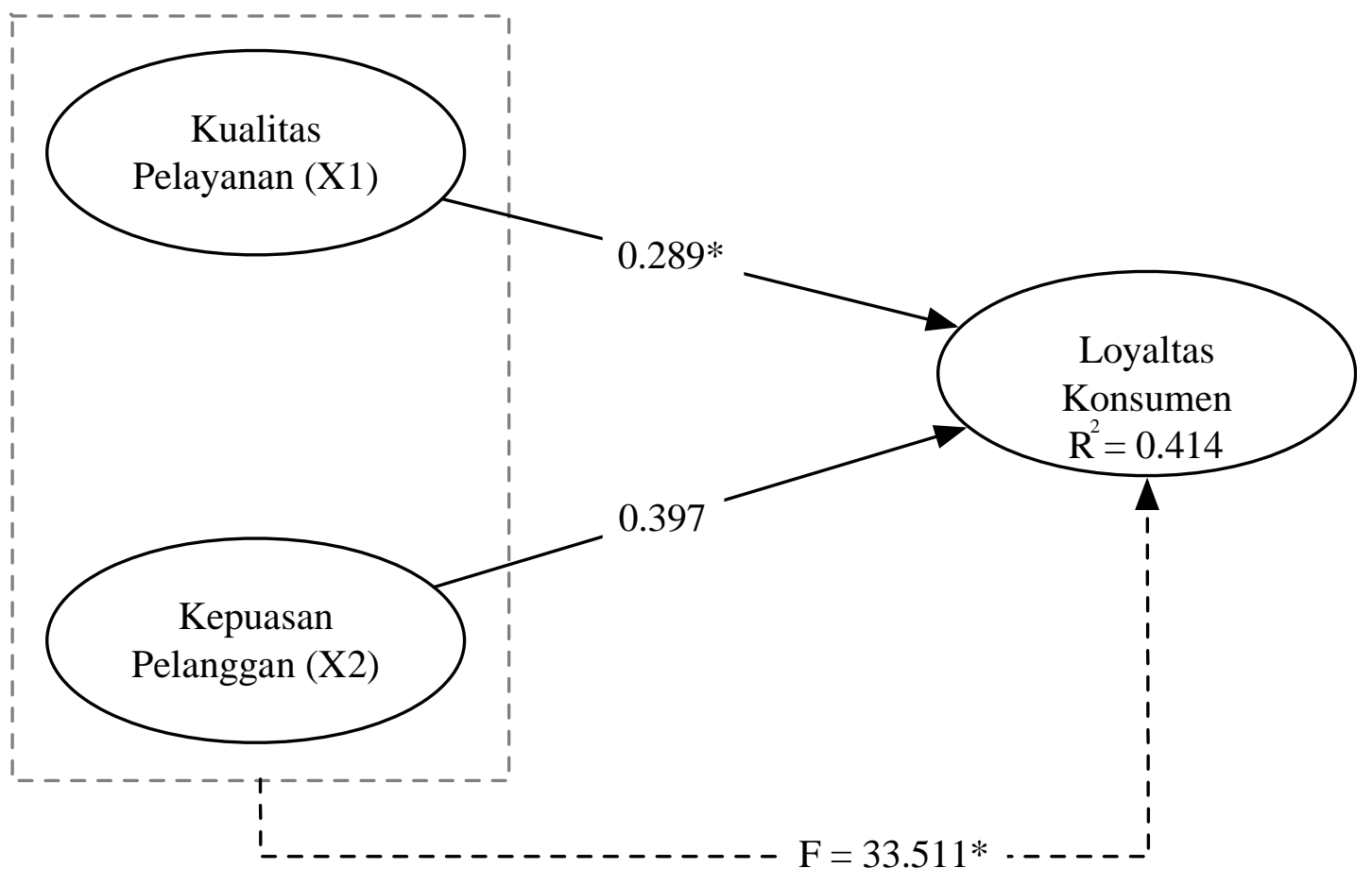

*signifikan pada level 0.05

Gambar 1. Hasil Pengujian Model

Sumber: Hasil olah data SPSS, 2019

\section{Hasil Uji Selisih Mutlak}

Pengujian terhadap Uji Selisih Mutlak dilakukan untuk menjawab hipotesis ke 3 (tiga) yaitu kualitas pelayanan (X1) mempengaruhi loyalitas konsumen (Y) melalui variabel pemoderasi yaitu kepuasan konsumen (X2). Uji ini dipakai untuk mengurangi efek multikolonieritas serta menghasilkan implikasi yang lebih baik dari variabel independen/bebasnya pada variabel dependennya (Frucot dan Shearon, 1991, dalam Ghozali, 2013:235). Hasil uji Moderated Regression Analysis (MRA) dengan uji nilai selisih mutlak sebagai berikut:

Tabel 5 : Hasil Uji Selisih Multak Pengaruh Kualitas Pelayanan, Kepuasan Konsumen terhadap Loyalitas Konsumen

\begin{tabular}{|l|r|r|r|l|}
\hline Variabel Independen & \multicolumn{1}{|c|}{ Beta } & \multicolumn{1}{|c|}{ Sig. } & \multicolumn{1}{c|}{ T-hitung } & Keterangan \\
\hline Constant & 12,985 & & & \\
\hline Zsore-Kualitas Pelayanan (X1) & 0.681 & 0.00 & 4.080 & Signifikan \\
\hline Zscore-Kepuasan Konsumen (X2) & 0.885 & 0.00 & 5.314 & Signifikan \\
\hline Abs ZX1_ZX2 & 0.359 & 0.157 & 1.426 & Tidak Signifikan \\
\hline
\end{tabular}

Variabel Dependen: Loyalitas Konsumen (Y)

Sumber: Hasil Olah Data SPSS, 2019

Pembahasan

Pengaruh Kualitas Pelayanan terhadap Loyalitas Konsumen yang diukur melalui 5 
dimensi pelayanan yaitu tangible (bukti fisik), reliability (kehandalan), responsivennes (ketanggapan), assurance (jaminan), dan empathy (empati) dalam penelitian ini menunjukan hasil yang signifikan dan mampu mempengaruhi loyalitas konsumen. Hal ini sejalan dengan penelitian Kumalaningrum, dkk (2016) yang turut meperkuat pendapat semakin tinggi kualitas pelayanan yang ditawarkan oleh perusahaan, maka semakin tinggi pula tingkat loyalitas konsumen perusahaan tersebut. Penelitian ini memiliki implikasi bahwa Gojek selaku perusahaan penyedia jasa transportasi dan penyedia layanan lainnya tersebut senantiasa terus menerus meningkatkan kualitas pelayanan dan memberikan pelayanan terbaik bagi kosumennya agar loyalitas konsumen semakin tinggi.

Pengaruh Kepuasan Konsumen terhadap Loyalitas Konsumen menunjukkan hasil penelitian yang juga menunjukan nilai signifikan untuk variabel kepuasan konsumen terhadap loyalitas konsumen. Ini juga mengindikasikan hubungan positif dan searah antara ke dua variabel tersebut. Semakin tinggi kepuasan konsumen, semakin besar pula tingkat loyalitas konsumen. Hal ini sejalan dengan hasil penelitian Fatona (2010) dan Pramono (2012).

Implikasi penelitian ini dapat dikatakan bahwa perusahaan harus senantiasa memahami aspek-aspek yang mampu membentuk kepuasan pelanggan seperti kualitas pelayanan itu sendiri, kepuasan pelanggan dalam rangka memakai produk Gojek itu sendiri ataupun aspek lainnya seperti reward kepada pelanggan setia.

Pengaruh Kualitas Pelayanan terhadap Loyalitas Konsumen melalui Kepuasan Konsumen menunjukkan hasil uji mutlak yang menguji pengaruh kualitas pelayanan terhadap loyalitas konsumen melalui kepuasan konsumen gagal dibuktikan dalam penelitian ini. Hal ini tidak sejalan dengan penelitian Kumalaningrum, dkk (2016) dan Pramono (2012). Walaupun penelitian ini menunjukan hasil yang tidak signifikan namun nilai positif yang dihasilkan dari uji hasil mutlak mampu menunjukan hubungan searah antara kualitas pelayanan terhadap loyalitas konsumen melalui kepuasan konsumen.

Secara implikasi penelitian, perusahaan Gojek dapat senantiasa menjaga kualitas pelayanannya agar loyalitas konsumen semakin meningkat demikian pula untuk kepuasan pelanggannya. Adanya hasil yang tidak signifikan antara hubungan kualitas layanan dan loyalitas konsumen dengan kepuasan konsumen sebagai variabel intervining juga ditemukan dalam penelitian Putri dan Utomo (2017). Dimana hasil tersebut menganggap variabel kepuasan konsumen harusnya menjadi variabel independen dan bukan sebagai variabel intervining mengingat kontribusi variabel ini secara teori dapat berkontribusi cukup besar untuk nilai loyalitas konsumen

\section{KESIMPULAN DAN SARAN}

\section{Kesimpulan}

Berdasarkan hasil penelitian diketahui bahwa variabel kualitas pelayanan maupun kepuasan konsumen mampu mempengaruhi baik secara partial maupun simultan terhadap loyalitas konsumen yang dibuktikan dengan hasil uji $\mathrm{t}$ dan uji $\mathrm{f}$ yang berada di bawah level of significant $5 \%$. Sedangkan berdasarkan hasil uji selisih mutlak pengaruh kualitas pelayanan terhadap loyalitas konsumen melalui kepuasan konsumen tidak dapat dibuktikan. Hal ini yang perlu dikaji lebih lanjut, mengingat banyak faktor lain 
yang mampu mempengaruhi loyalitas seperti faktor kepercayaan konsumen.

\section{Saran}

Berdasarkan nilai Adjust R Square yang diperoleh penelitian ini yaitu sebesar 0.401 yang berarti pengaruh kualitas pelayanan dan kepuasan pelanggan mampu mempengaruhi loyalitas konsumen cukup rendah yaitu sebesar $40.1 \%$ dan sisanya sebesar $59.9 \%$ dipengaruhi oleh faktor lain yang tidak diteliti dalam penelitian ini. Hal ini dapat menjadi bahan pertimbangan bagi peneliti lainnya untuk meneliti faktor yang mampu mempengaruhi loyalitas konsumen kedepannya ditambah menjadikan faktor kepuasan konsumen sebagai variabel independen.

\section{DAFTAR PUSTAKA}

Askari, Naqi, dkk. 2014. Pengaruh Kualitas Pelayanan terhadap Loyalitas Pelanggan Melalui Kepuasan Pelanggan (Bagian Service PT. Nasmoco Gombel Semarang). Diponegoro Journal Of social And Political Science. Fakultas Ilmu Sosial dan Ilmu Politik. Universitas Diponegoro.

Bastos, J. and Gallego, P.M., 2008, Pharmacies Customer Satisfaction and Loyalty - A Framework Analysis. Document de Trabajo Nuevas Tendencias En Direccion De Empresas, Miguel de Unamuno, Espana

Bulkia, S. (2018). PENGARUH KUALITAS PELAYANAN TERHADAP KEPUASAN MAHASISWA. AtTadbir: jurnal ilmiah manajemen, 2(1).

C. Mowen, John. Michael Minor. 2002. Perilaku Konsumen. Jakarta. Erlangga

D Gremler, Dwayne, Jo Bitner, Mary and A Zeithaml, Valarie. 2009. Services Marketing Integrating Customer Focus Across The Firm (Fifth edition). Singapore: MC Graw Hill

Deng, Z., Lu, Y., Wei, K. K., dan Zhang, J. (2010). Understanding Customers
Satisfaction and Loyalty: An Empirical Study of Mobile Instant Messages in China. International Journal of Information management, 30(2010), 289300. Retrieved from Sience Direct Journal Database.

Fatona, siti. 2010. Kualitas Jaya Yang Mempengaruhi Loyalitas Konsumen Dan Relevansinya Terhadap Kepuasan. Jurnal Dinamika Manajemen Vol 1, Halaman 41-46. Sekolah Tinggi Ilmu ekonomi Adi Unggul Bhirawa, Surakarta

Griffin, Jill.(2005). Customer Loyalty : Menumbuhkan dan Mempertahankan Kesetiaan Pelanggan. Alih bahasa : Dwi Kartini Yahya dan kawan kawan. Erlangga, Jakarta.

Gujarati, D.N.,2012,Dasar-dasar Ekonometrika, Terjemahan Mangunsong,R.C.,Salemba Empat, buku 2, Edisi 5, Jakarta

Ghozali, Imam. 2013. Aplikasi Analisis Multivariat dengan Program IBM SPSS. Edisi 7. Semarang: Penerbit Universitas Diponegoro

Hurriyati, Ratih. 2008. Bauran Pemasaran dan Loyalitas Konsumen. Bandung: CV. Alfabeta

James G., (2003). Secrets Of Customer Relationship Management, ANDI, Yogyakarta

Kotler, Philip, 2007, Dasar-Dasar Pemasaran, Indeks Kelompok Gramedia, Jakarta.

Kumalaningrum, Febri, dkk. 2016. Analisa Pengaruh Kualitas Pelayanan Terhadap Loyalitas Konsumen Dengan Kepuasan Konsumen Sebagai Variabel Moderasi (Studi Pada Kosnumen CS Kopi Tubruk Surakarta). Jurnal Ekonomi dan Kewirausahaan Vol. 16 No. 2 Juni 2016: halaman 226 - 233. Universitas Slamet Riyadi Surakarta.

Luhur Eko Pramono, 2012, Analisis Pengaruh Kualitas Pelayanan Terhadap Loyalitas Pelanggan dengan Kepuasan Pelanggan sebagai Variabel Moderating (Studi kasus pada Warung Makan Bebek Goreng Haji Slamet Kartasura), Skripsi (tidak dipublikasikan), Fakultas 
Ekonomi, Universitas Muhammadiyah Surakarta.

Lovelock, Christopher H. dan Lauren K Wright. 2005. Manajemen Pemasaran Jasa,Penerbit Indeks, Jakarta.

Kotler, Philip. 2007. Manajemen Pemasaran. Jakarta : PT.Indeks

Philip Khotler dan Kevin Lane Keller. 2009. Manajemen Pemasaran. Indeks. PT. Macanan Jaya Cemerlang. JakartaSugiyono. 2016. Metodologi Penelitian Kuantitatif, Kualitatif, dan R\&D. Bandung: CV Alfabeta

Putri, Yulia Larasati dan Utomo Hardi. 2017. Pengaruh Kualitas Pelayanan Terhadap Loyalitas Pelanggan Dengan Kepuasan Sebagai Variabel Intervening (Studi Persepsi Pada Pelanggan Dian Comp Ambarawa). Jurnal Among Makarti Vol.10 No.19.
Singgih Santoso. 2002. SPSS Versi 11.5 Cetakan Kedua Jakarta: Gramedia

Stanton. William J. 1986. Prinsip Pemasaran. Jakarta. Erlangga

Tjiptono. Fandy. 2006. Manajemen Jasa. Cv Andy Offset. Yogyakarta

Wicaksono, T. (2017). Pengaruh Dimensi Kualitas Pelayanan Terhadap Kepuasan Pelanggan Pada Upik Futsal Banjarmasin. At-Tadbir: jurnal ilmiah manajemen, 1(2).

Wilkie, William L. 1994.Customer Behavior (Third Edition). New York. Jhon Wiley\& Sons, Inc, $\mathrm{s}$

Zeithaml,Valarie A and Bitner. (2000). Service Marketing 2nd edition : Integrating Customer Focus. New York.McGraw-Hill Inc.

Zeithaml, V. A., et al. (2009). Service Marketing (5th Ed). New York: McGraw Hill. 